\title{
A Study on the Blending Mode of Translation MOOC and English Classroom Teaching
}

Ling Ma

Foreign Language College, Shihezi University, Shihezi 832000, Xinjiang, China. E-mail: lzd304@163.com

Abstract: With the popularization and application of Internet in the field of education, English classroom teaching should also conform to the trend of the times and strengthen the application of modern information technology. In this regard, this paper explores the integration mode of translation MOOC and English classroom teaching, in order to fully meet the needs of contemporary students' personalized development and promote their all-round development.

Keywords: Translation MOOC; English Classroom Teaching; Blending Mode

The "Internet +" education mode has posed a great challenge to the traditional educational ecology, and has brought the "MOOC" and "flipped classroom" into people's vision. At the same time, it has become an inevitable trend of the future development of higher education in China. How to make effective use of resources to improve the effect of English classroom teaching? This is a question worthy of deep consideration by college English teachers in China.

\section{The rise and characteristics of MOOC}

MOOC is a large-scale open online course, which takes the Internet as the platform and combines various elements such as lecture videos, homework exercises, forum activities, tests and examinations, enabling people to participate in large-scale activities. The essential reason for the rise of $\mathrm{MOOC}$ is that people have a good vision of fair and democratic education since ancient times. Its main characteristics include the following three points: first, online. MOOC based on the Internet can enable students to learn independently according to their own actual situation, and teachers can also timely adjust the learning plan according to the background data recording and analysis, so as to maximize the teaching effect; second, open. The essence of MOOC is a large-scale open online course. Its opening is not only reflected in the opening of teaching resources, but also in the whole process of teaching, such as teaching philosophy, teaching interaction, teaching evaluation, and so on, which truly realizes student-centered; thirdly, teaching evaluation is diversified and timely.

\section{An analysis of the current situation of English classroom teaching}

The level of translation ability directly affects the development of students' comprehensive English ability. However, some colleges and universities in China do not pay enough attention to translation teaching in English classroom teaching. They still focus on the training of reading, writing and listening and usually only explain some fragmentary translation knowledge to students when they explain English articles or listening materials. That is to say, students do not accept systematic translation learning, so they can only cram for the moment in the face of translation practice. At the same time, most of the college English classroom teaching is still teacher-centered, which makes students easily lose their attention to the teaching content and interest and enthusiasm for English learning, thus the learning effect is naturally unsatisfactory.

Copyright $\odot 2020$ Ling Ma

doi: $10.18686 /$ ahe.v4i10.2905

This is an open-access article distributed under the terms of the Creative Commons Attribution Non-Commercial License (http://creativecommons. org/licenses/by-nc/4.0/), which permits unrestricted non-commercial use, distribution, and reproduction in any medium, provided the original work is properly cited. 


\section{Teaching dilemma of the needs of the times and blending mechanism in English teaching}

\subsection{The needs of the times in English teaching}

With the rapid development of society, college English teaching must comply with the development trend and demand of the times, and MOOC, as an important learning method, should be paid enough attention to by colleges and universities in China. If college English teachers can't make full and active use of modern information technology, it will not only increase their own teaching burden, but also affect students' learning efficiency and effect, as well as the pace of development in the field of education. Therefore, college English teachers should continue to explore the use of various modern information technology teaching methods in the actual teaching process. For example, the effective combination of translation MOOC and classroom teaching content can meet the needs of students' personalized development to a large extent, and even further achieve the teaching purpose in accordance with their aptitude.

\subsection{Teaching dilemma faced by blending mode}

Firstly, there are some differences among students in English foundation, learning interest and learning ability, which requires that the setting of integration mechanism should fully consider the actual situation of each student. For example, the online learning of translation MOOC should be set as plus sub items, so that students can make their own choices according to their actual situation. Secondly, the running in mode of translation MOOCS and English classroom teaching needs to adopt the "online + offline" teaching mode, which poses a higher challenge to both teachers and students, because the join of translation MOOC requires teachers and students to apply a large number of online teaching platforms, but many teachers and students are not familiar with the operation of online courses. It is necessary to receive professional and patient guidance from the platform technicians.

\section{The concrete implementation strategy of MOOC and classroom blending mode}

First of all, a teaching team is set up to complete the translation series of micro courses in spare time. Secondly, based on the high-quality network teaching platform, the teaching content of offline classroom can be promoted, managed and broadened. The specific implementation methods are as follows:

\subsection{Preparing and analyzing pre-class materials}

Before teaching, the team of teachers should plan the teaching content according to the teaching objectives and syllabus to refine the knowledge points and find out the relationship between them. On this basis, we design reasonable MOOC courses in groups and batches in strict accordance with the syllabus. The video resources provided by MOOC are very important for students. With these videos, students can arrange their own learning plans according to their learning progress and learning ability. Because MOOC video is not limited by the time and space of traditional teaching class, students can watch and learn at any time whether in class or after class, so that the learning environment will be more relaxed without pressure. At the same time, each student can use the account number provided by the network teaching platform and the teaching class group to communicate with teachers and students at any time during the learning process, which is conducive to solve the problems they encounter in time. Before the formal teaching, students can be assigned preview tasks, which can reduce the classroom time that teachers need to take up in class to a certain extent, and enable students to have more classroom learning time available for their own control, which plays an important role in improving students' comprehensive English ability. It is important to note that after the teaching objectives are refined, the number, length and content of MOOC videos should be designed reasonably. For example, in the process of English translation teaching, teachers can introduce students with theoretical knowledge such as translation strategies and the characteristics of English-Chinese translation differences in short video, which will help students to understand the teaching content as a whole.

\subsection{Organizing classroom knowledge points and activity design}

As a professional language discipline, English translation is difficult for most students to understand, which will affect the enthusiasm of students in learning English to a large extent, and even produce fear and resistance to English learning. In view 
of this situation, English teachers can use the diversity and visualization of MOOC to arouse students' interest in learning. In addition, a great advantage of the blending teaching mode of English class based on translation MOOC is that it can complete the teaching task of imparting knowledge before the formal class, and take the formal teaching class as a link to help students digest knowledge. Therefore, the organization of classroom knowledge points and activity design is particularly important. As English translation has a strong practicality, the organization of classroom knowledge points and design activities should be combined with some practical cases closely related to students' life, so as to help students form a more comprehensive and three-dimensional understanding of English translation; at the same time, teachers can guide students to complete some related exercises after summarizing and decomposing the knowledge points. The purpose of this is to inspire and cultivate students to form the habit of thinking dialectically and independently.

\subsection{Strengthening the interaction and supervision after class}

When constructing the blending teaching mode of translation MOOC and English classroom teaching, in addition to the current classroom activities, English teachers should also communicate with students as much as possible after class, so as to strengthen the supervision and management of students' learning after class, and ensure that they can learn effectively after class. For example, through the analysis of the number of hits and views of teaching videos watched by students, we can understand the students' learning situation of videos watching before and after class. On the one hand, if students watch the teaching video before class, teachers can arrange exercises for students on the Internet. Of course, for students with good academic performance, they can appropriately increase the amount of practice or the difficulty of practice, so as to teach students according to their aptitude and meet the needs of students' personalized development. The students complete these excises and submit, and then the teacher will review them on the network. In the actual teaching class, teacher can explain the problems in the exercises in detail for the students, so as to completely eliminate the doubts of the students, help the students better understand and master the content they have learned. On the other hand, it is also necessary to monitor whether the students have carried out consolidation exercises after class, in order to avoid the flipped classroom being superficial due to students' laziness, which leads to the unsatisfied teaching effect. We should not only pay attention to the interaction between teachers and students, but also strengthen the interaction between students and students. For example, teachers can establish a class communication group with the help of the network. Students can put forward questions to teachers in the group, and can also exchange and discuss learning related issues with classmates.

\section{Conclusion}

To sum up, compared with the traditional English classroom teaching, the integration of translation MOOC can stimulate students' interest and enthusiasm in learning to a certain extent, mobilize students' learning enthusiasm and subjective initiative, and effectively improve students' learning efficiency and effect. At the same time, the introduction of translation MOOC can also help improve students' abilities in translation and writing. In addition, MOOC can easily realize the teaching expectation of teaching students in accordance with their aptitude, so as to make fair and reasonable teaching evaluation for students.

\section{References}

1. Wang L. A study on the blending mode of translation MOOC and English classroom teaching. Journal of Hubei Open Vocational College 2020; (12): 159-160.

2. Zhang X. Research on the blending teaching mode of professional English translation based on MOOC and flipped classroom. Journal of Heilongjiang University of Education 2019; (05): 139-141.

3. Ai M. The application of flipped classroom in college English translation teaching under the background of MOOC. Intelligence 2018; (10): 93. 